\title{
16
}

\section{Parentalization of Same-Sex Couples: Family Formation and Leave Rights in Five Northern European Countries}

\author{
Marie Evertsson, Eva Jaspers, and Ylva Moberg
}

As discussed extensively in this volume, policies have important implications for how families are formed and how they live their lives. Family leave policies, among other things, enable parents to take job-protected leaves from work to care for a newly born or adopted child and/or to take time off from work when a child is ill. However, factors such as the length of any job-protected leave, the levels of reimbursement, and the number of eligible policy users vary among countries. The degree to which individuals can make use of family leave policies also varies and is partly dependent on the extent to which they fit the legally recognized version of a parent. The family policy system was designed to cater to the heteronormative family, i.e., a (preferably married) mother and father with joint children. As new family constellations emerge and are legally recognized, it is important to study whether and to what extent the policies designed for the heterosexual, nuclear family also encompass other families.

\footnotetext{
M. Evertsson $(\varangle) \cdot$ Y. Moberg

Swedish Institute for Social Research (SOFI),

Stockholm University, Stockholm, Sweden

e-mail: marie.evertsson@sofi.su.se

Y. Moberg

e-mail: ylva.moberg@sofi.su.se

E. Jaspers

Department of Sociology/ICS, Utrecht University, Utrecht, The Netherlands e-mail: e.jaspers@uu.nl
} 
In this chapter, we enhance theories of welfare state development by introducing the concept of parentalization. Parentalization is defined as the ability to become parents and be recognized as such, both legally and via social policies. To demonstrate an application of this new concept, we examine how states facilitate or hinder parentalization through laws and policies for same-sex parent families. We focus on five countries that were among the first to legalize same-sex unions/marriages and parenthood: the four larger Nordic countries (Denmark, Finland, Norway, and Sweden) and the Netherlands. Whereas the Netherlands is known as a LGBTQI-friendly ${ }^{1}$ nation with moderately generous family leave policies, the Nordic countries are considered among the most family-friendly in the world, partly due to their generous family leave policies in terms of length as well as reimbursement levels. By mapping the paths to legally recognized same-sex parenthood and family policy rights, we can identify obstacles and hurdles on the road to full parentalization for couples in these countries.

Parentalization is operationalized as the extent to which individuals can (i) transition to legally recognized parenthood and (ii) make use of family leave policies to care for the child (in our example, parental, maternity, and paternity leaves). Both (i) and (ii) can be accessible in theory but more or less hard to achieve in practice. Parentalization, or the notion of who has the rights and possibilities to become a parent and who is excluded from parenthood and/or the policies that come with it, is closely linked to gender and norms regarding motherhood and fatherhood. We discuss family leave policies from the perspective of same-sex parent families in the countries in focus, demonstrating how the parentalization concept and the resulting analysis facilitate an understanding of how national policies contribute to or create (in)equalities between various groups of parents(-to-be). In conclusion, we briefly discuss the parentalization concept from the perspective of family constellations not analyzed in this chapter and arrive at a research agenda for the future.

\section{Parentalization: A First Restricted Analysis}

Variation in the definitions of what constitutes a family, both socially and legally, facilitates for certain groups and hinders others from forming legally recognized unions, having children and being the kind of parent they would like to be, for instance, by making use of family policies. Family law, its

${ }^{1}$ LGBTQI is short for lesbian, gay, bisexual, transgender, queer, and intersex. 
rules and regulations, formalizes not only individuals' rights, and obligations towards one another but also the extent to which society and the state have obligations toward the family and its members. The definition of a family that the state applies is based on the legal recognition of a parent-child relationship and determines who has authority over a child, who may act as a child's representative and who is eligible for family benefits. Not being legally recognized as a parent may, among other things, mean not being able to pick up prescribed medicine at the pharmacy if the child is ill, risking losing custody in case of divorce or the other parent's death and not being able to pass on financial assets via inheritance to the child without a written testimony.

Parentalization as a concept can be used to analyze a number of various groups and family constellations. The focus on same-sex couples in this chapter is motivated by the aim to link the analysis to access to family leave policies, which are more readily available and commonly used when children are small. Notably though, same-sex parent families often find it easier to fit within the definition of a family than do other groups such as single gay fathers, transgender individuals, or non-biological parents in multi-parent families $^{2}$ (e.g., Carroll, 2018; Downing, 2013). When we refer to same-sex couples, we base the definition on the categories of woman/man as defined in population registers i.e., a person's legal gender. Hence, we may include individuals defining themselves as man, woman, both or neither. We do not distinguish identities linked to ethnicity, social class, or other aspects even though they in many ways structure an individual's transition to and experiences of parenthood (e.g., Carroll, 2018; Moore, 2011).

Before we turn to the practical details of how policies work, we briefly discuss the welfare regime and social policy frameworks. The aim is to show how the concept of parentalization expands on these frameworks by recognizing the problems that same-sex couples and other couples may face in realizing their (any) parenthood ambitions. In other words, to be parentalized both (i) through the legal system and (ii) through the policy system.

\footnotetext{
${ }^{2}$ We define a multi-parent family as a group of individuals linked by parent-child relations in a context where three or more parents share in the active parenthood for the same child/children. None of the countries in focus in this chapter recognize more than two legal parents. Still, it has not been uncommon among same-sex couples to form families that include more than two parents (willing and committed to act as parents for the child), especially in periods before joint adoption and assisted procreation was legally recognized for same-sex couples.
} 


\section{Queering the Welfare Regime Perspective: A Call for a New Focus}

In early works, Titmuss (1958) categorized social policies as 'residual' or 'institutional,' where the former term refers to weaker policy systems based on a safety-net in case of market failure, and the latter term refers to more comprehensive institutional systems that are often based on notions of social rights. Building on this categorization, the modern welfare regime literature accumulated, especially during the 1980s and 1990s. A cornerstone in this tradition is Gøsta Esping-Andersen's Three Worlds of Welfare Capitalism (1990), in which he outlines three main types of welfare regimes, i.e., the liberal, the social democratic, and the conservative, in which he claims that modern developed capitalist nations cluster. ${ }^{3}$ He states that the ways in which nations choose to divide welfare responsibilities between the family, the market and the state are important. Esping-Andersen also discusses the concept of decommodification, i.e., social transfers and social insurances that enable workers to survive during periods when they are unable to sell their labor as a commodity in the market (Esping-Andersen, 1990, 1999).

Esping-Andersen's categorization has, among other things, been criticized for neglecting gender and for departing from an implicitly male, social class perspective (e.g., Lewis, 1992; Orloff, 1993). Lister (1994, p. 37) has termed the concept of defamilialisation (from here on referred to as defamilialization) to capture ... the degree to which individuals can uphold a socially acceptable standard of living, independently of family relationships, either through paid work or through the social security system. This concept parallels the concept of decommodification. It highlights how many women would like to be commodified i.e., to have access to paid employment that frees them from their unpaid work and their economic dependency on a spouse, as well as to social security provisions in periods when they are unable to work (see Chapter 6 by Zagel and Lohman in this volume for a more detailed discussion of how this concept has been defined and used). Since then, the welfare and gender regime literature has been updated and modified, resulting in a number of publications on social citizenship, family policy frameworks, and gender regimes. A significant amount of this literature has focused on mothers' ability to combine periods of (infant) care with long-term access to paid work and to avoid falling into poverty if they are in an autonomous household (e.g., Keck \& Saraceno, 2013; Korpi, Ferrarini, \& Englund, 2013; Leitner, 2010, Misra, Budig, \& Moller, 2007). An ever-increasing field of

\footnotetext{
${ }^{3}$ The categorization was far from encompassing and had a distinct Western European focus.
} 
literature has also explored the extent to which family policies enable men to be caregivers as well as earners (e.g., Eydal et al., 2015; Grunow \& Evertsson, 2016; Haas \& Rostgaard, 2011; Saraceno \& Keck, 2011). Taken together though, the literature largely implies the perspective of the heteronormative family, assuming one male and one female as partners in households that raise children.

The five countries in focus in this chapter differ to some extent in terms of their welfare and gender regimes. The Nordic countries belong to the social democratic welfare regime, with universalistic systems that promote the equality of good standards instead of minimal needs. This implies decommodifying welfare state services that reduce inequalities that are introduced by market-based access to services. The degree of defamilialization is considered high because of long job-protected parental leaves and highly subsidized public childcare. However, as typologies refer to one time point and are ideal types, there are ambiguous cases as well as transmutations (cf. EspingAndersen, 1999, p. 86). In the Nordic countries, Finland has been discussed as a country that may be closer to the conservative cluster than the others. The Netherlands was originally part of the conservative regime cluster shaped by traditional and gendered family values that encourage family-based assistance dynamics. Over time, the Netherlands has moved toward a more mixed regime, wherein some parts of care work have become defamilialized (especially care for the elderly population) (Reimat, 2019).

The welfare and gender regime perspectives have had important theoretical as well as practical implications for how family policies were designed and implemented. However, today, new issues are on the agenda. Among these are a need to focus on the growing share of families that do not fit the heteronormative family norm. Historically, states have granted rights to men and women based on their statuses in families (Lewis, 1992). As wives and mothers, women have been granted certain rights with respect to maternity and parental leave, widowhood pensions and child benefits (Lewis, 1992). As workers, men have been granted with more or less social security rights, depending on the specific welfare regime of their state (Esping-Andersen, 1990, 1999; Korpi, 2000). Family leaves reserved for fathers have been either short or marginal. The gendered nature of policies linked to unpaid and care work, combined with heteronormative beliefs about proper gender roles, has contributed to same-sex couples facing different constraints than those faced by different-sex couples in regard to parentalization. The next step in the gender regime literature is thus, as we see it, an analysis of the extent to which same-sex couples are able to realize any parenting desires they may have and 
the extent to which policies support their shared caring if or when they have children.

\section{Parentalization: A Gendered Concept}

We use the term parentalization as a concept divided into two parts, where the first has to do with individuals' or couples' ability to become parents. Evidence and experience show that the transition to parenthood is not only biologically but also socially facilitated for heterosexual couples. When different-sex couples have been unable to conceive, other avenues have been opened up, for instance, by adoption or fertility treatments. Access to these treatments was later granted to same-sex couples and has been implemented in ways that are not always appropriate for them. As an example, biological mothers-to-be often are given fertility stimulating medication that they may not need in order to become pregnant (Berg Hulthén \& Nordqvist, 2017).

Parentalization is a gendered concept, in the sense that women, as a rule, are often deemed better fitted for care work than men. Evidence of a preference for women as parents over men can, for instance, be found in European court rulings linked to family policies, which privilege the motherchild relationship (McGlynn, 2001). Women also seem more motivated and able to negotiate family-friendly work conditions than do men (e.g., Harris \& Estevez, 2017; McGlynn, 2001). In couples where there are either two mothers or two fathers, the norms and expectations linked to both heterosexuality and gender/parenthood are challenged. As we will show below, becoming a parent and making use of the policies facilitating the care of a child are currently, and have been, easier for female than for male same-sex couples. With a concept such as parentalization, we can critically evaluate the extent to which not only same-sex couples but also a broader range of couples who are not at the mental forefront of policy makers have the legal as well as the social rights that come with parenthood in various contexts and nations.

\section{Parentalization in Practice. Part 1: Who Can Become a Parent and How?}

Same-sex couples' access to medically assisted insemination (MAI) has varied over time and among countries. Same-sex parenthood is legally recognized in the majority of European countries (Waaldijk, 2018). However, even when it is recognized, same-sex couples often have to go through time-consuming and seldom inexpensive processes to become parents. Once the child/children 
arrive, they are often longed for and the parents are well prepared. Moreover, research indicates that the children brought up in these families fare at least as well and manage school as well as children of different-sex parents (e.g., Aldén, Björklund, \& Hammarstedt, 2017; Mazrekaj, De Witte, \& Cabus, 2019; Watkins, 2018).

To determine whether and how same-sex couples can (i) become parents and (ii) realize their ideal ways of parenting (which may include sharing parental leave, care for sick children, etc.), we start from an overview of when and by which avenues same-sex parenthood became legally available in the countries in focus. ${ }^{4}$ It is worth noting that, of course, many same-sex couples became parents long before this, even if it meant not being legally recognized as parents.

\section{Marriage and Parenthood Rights, Joint and Second-Parent Adoption}

The first step toward legally recognized parenthood for same-sex couples has, in many cases, been registered partnerships and/or marriage rights, due to the link to adoption rights. Table 16.1 gives an overview of when the rights and legislation concerning same-sex couples' ability to form families were implemented in the four Nordic countries and the Netherlands. In 1989, Denmark became the first country in the world to legally recognize same-sex relationships and was soon followed by Norway (1993), Sweden (1995), and the Netherlands (1998) (Frantzen, 2011; Waaldijk, 2017). ${ }^{5}$ Finland legalized registered partnerships in 2002. The Netherlands was the first country to allow same-sex marriage in 2001. Joint within-country adoption has been available to same-sex couples in the Netherlands since 2001, and international adoption has been available since 2009. ${ }^{6}$ In Denmark, Finland, and Norway, the right of second-parent adoption, i.e., the possibility of adopting

\footnotetext{
${ }^{4}$ The information we provide herein will in time be outdated, as laws and regulations are continuously revised. Hence, we provide this overview mainly as a description of the different routes to same-sex couples' parentalization in these countries.

${ }^{5}$ Sweden had a law recognizing cohabiting homosexual couples since 1988 . This law did not give same-sex couples rights similar to those of married couples, as did the partnership law of 1995, but it gave legal recognition similar to that of cohabiting heterosexual couples. https://www.qx.se/histor ien/110578/sambolagen-for-homos-infors/.

${ }^{6}$ In order to adopt, couples must have lived together for three years prior to the request (this also applies to different-sex couples).
} 
M. Evertsson et al.

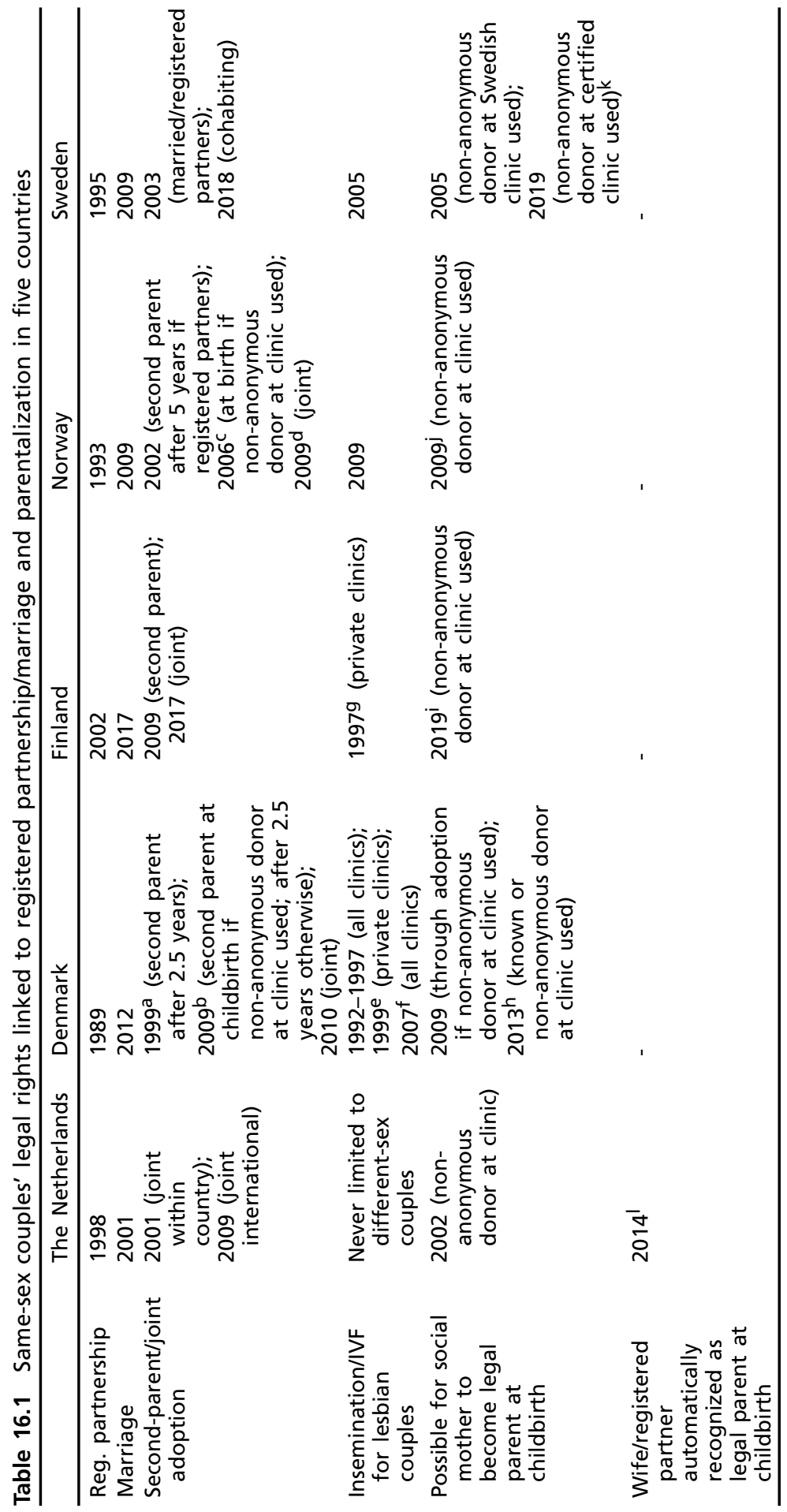




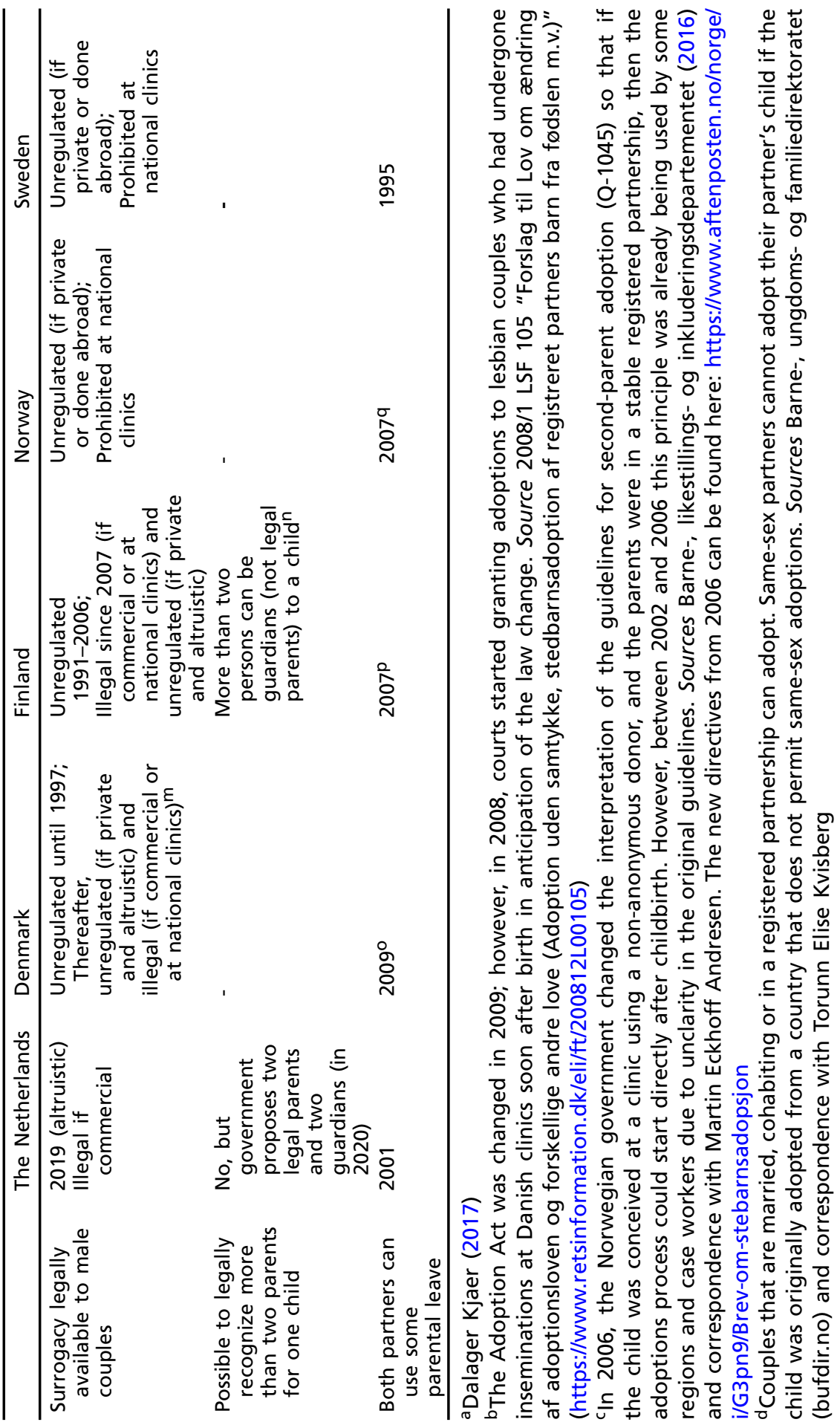




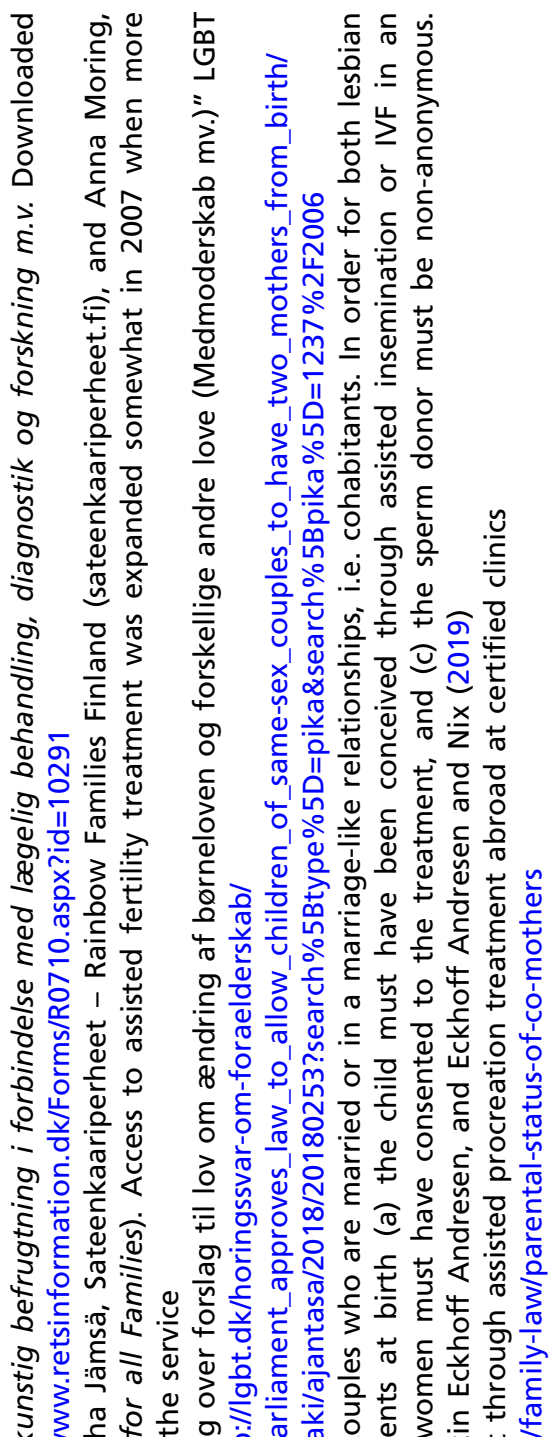

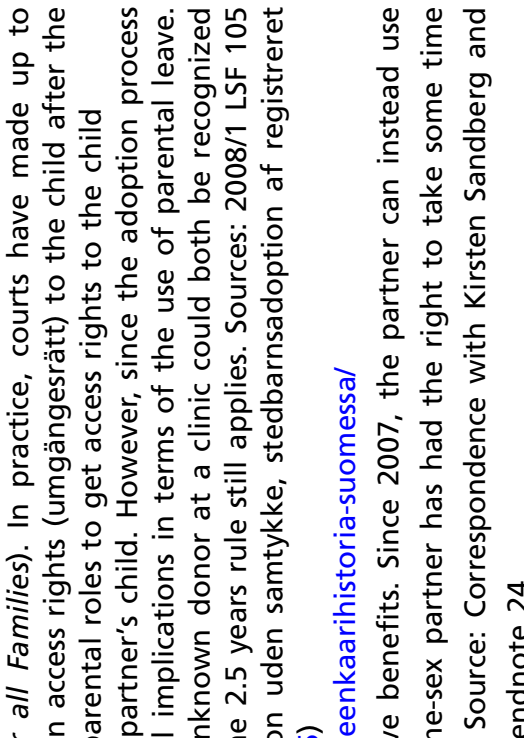

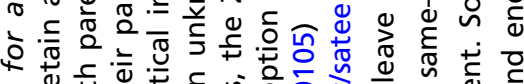

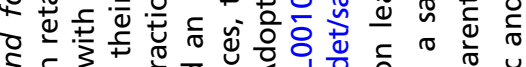
穴

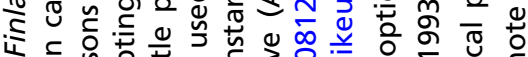

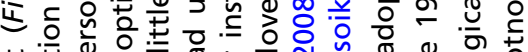

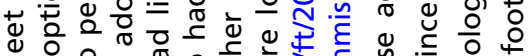

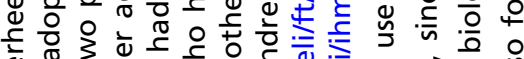
d



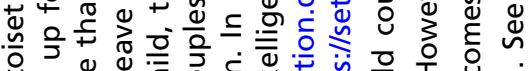

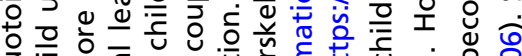

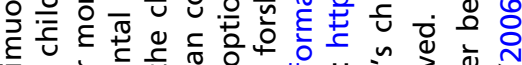

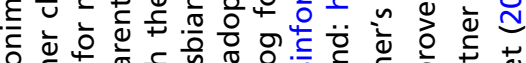

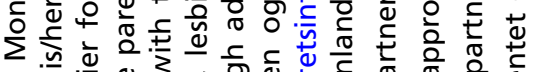

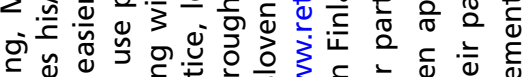

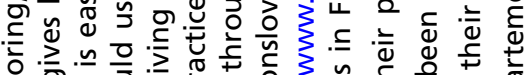

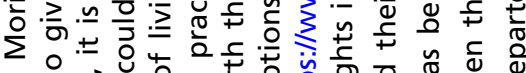
ס 원

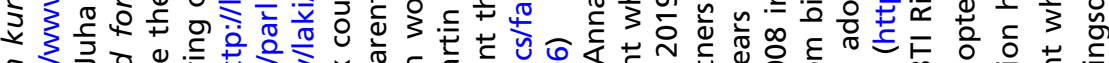

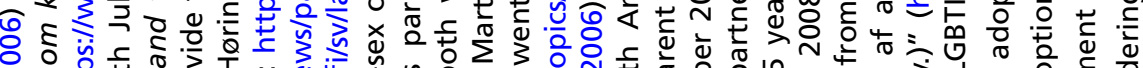

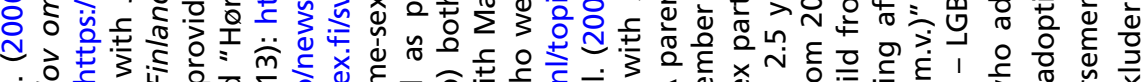

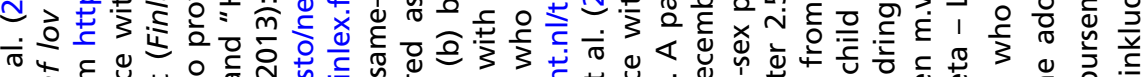

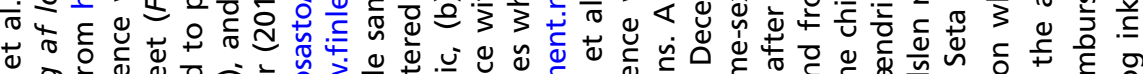

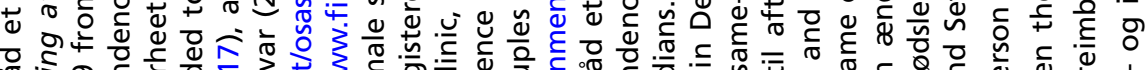

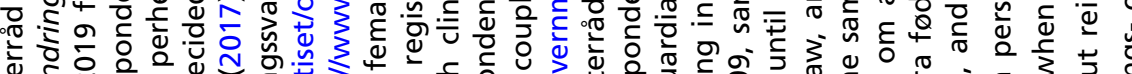



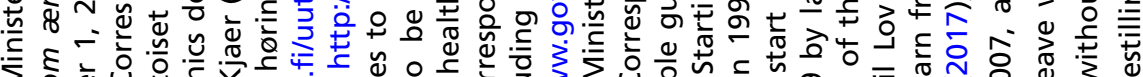

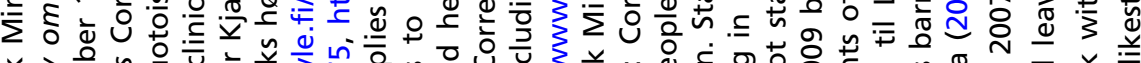

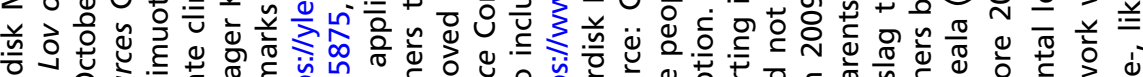




a spouse's child, proceeded the right of joint adoption (see Table 16.1). ${ }^{7}$ In Sweden, joint and second-parent adoption was made possible for same-sex parents in 2003. The right to joint adoption has been more of a formal than a practical right, as very few same-sex couples have been able to adopt a child. In some countries, second-parent adoption has been an increasingly important avenue to parenthood for male couples as a result of surrogacy arrangements.

\section{Medically Assisted Insemination/IVF and Female Couples' Transition to Parenthood}

For female same-sex couples, the right to medically assisted procreation has facilitated the transition to parenthood significantly. In the Netherlands, MAI is and always has been available to all women; there is no legislation limiting the categories regarding who can receive MAI or in vitro fertilization (IVF) (Nikolina, 2017a, 2017b). However, until 1998 (for MAI) and 2001 (for IVF), women in same-sex relationships or those without a partner were dependent on hospitals that were willing to assist them in medical procedures. Since 2002, the wife or registered partner of the birth mother can become a legal parent if the donor is unknown to the parents (i.e., from a sperm bank) but not anonymous (the child can determine who the donor is at age 16), by either legally recognizing the child before birth or via adoption after the birth. Since 2014, the wife/registered partner automatically becomes the child's legal parent in the case of an unknown donor. In practice, this means that the marriage presumption that covers different-sex couples-which by default assumes that the man of a married birth mother is the child's other parent-as of 2014 also includes female same-sex couples. Using a private, known donor, such as a friend or a relative, is more common in the Netherlands than in the Nordic countries; private insemination at home has been widely advocated in the Netherlands for a long time. ${ }^{8,9}$

\footnotetext{
${ }^{7}$ It is worth noting that in Finland and the Netherlands, the non-biological parent could also gain parental authority, i.e. represent the child and make decisions on his or her behalf, under certain conditions before formal adoption was legally available, if the legal parent consented (Nikolina, 2017b; Valleala, 2017).

${ }^{8}$ See for example: https://www.freya.nl/brochures/zelfinseminatie/.

${ }^{9}$ In addition, it seems private donors can more easily choose not to legally acknowledge biological fatherhood in the Netherlands. A biological father who is not married to or in a registered partnership with the birth mother needs the birth mother's written permission in order to legally acknowledge the child and cannot do so if the mother's (male or female) legal partner has already acknowledged the child. In Denmark, a known donor can avoid legal fatherhood, provided that the insemination is performed at a fertility clinic (Dalager Kjaer, 2017, p. 8). In Sweden, the same thing is possible if the donation is done through the public health care system in which the donor is first approved. In
} 
As Table 16.1 shows, MAI and IVF have been possible for female samesex couples since 1992 in Denmark, 1997 in Finland, ${ }^{10} 2005$ in Sweden, and 2009 in Norway. In Denmark, this right was taken away from lesbian couples in 1997, until private clinics found a loophole in the law in 1999. ${ }^{11}$ In the Nordic countries, there is no marriage presumption for same-sex couples, and the social mother has to go through a process similar to the one that cohabiting different-sex couples go through in order to legally verify their parenthood (see for Denmark: Dalager Kjaer, 2017; Norway: Eckhoff Andresen \& Nix, 2019; Sweden: www.rfsl.se; and Finland: Moderskapslag 20.4.2018/253). In Sweden, until 2019, if the child was conceived abroad, ${ }^{12}$ the social mother had to adopt the child, and for her to adopt, the couple needed to be married/registered partners. Today, if the donor is non-anonymous and the MAI/IVF is carried out at a certified clinic, then the social mother can confirm her parenthood and adoption is not needed (Zimmerman \& Nordqvist, 2018). In Denmark, the social mother initially had to adopt the child to become legally recognized as a parent (Table 16.1). However, since 2013, adoption is not needed when the child is conceived with MAI/IVF. In Norway, the birth mother's partner (via marriage or in a stable cohabiting relationship) can register as the child's legal parent from birth given that the biological mother consents and the child was conceived at a clinic using a non-anonymous donor (Eckhoff Andresen \& Nix, 2019; Frantzen, 2011; SOU, 2016:11). ${ }^{13}$ Being somewhat of a laggard, in April 2019, Finland passed a citizens' initiative that made it possible for both women in same-sex couples to be recognized as mothers from the moment their child is born (seta.fi, Moderskapslag 20.4.2018/253).

It has not been uncommon for same-sex couples to jointly have children with a single mother/father or another couple. However, a child can

\footnotetext{
Norway and Finland, however, a man who donates to e.g., a friend cannot avoid being recognized as the father. If a known donor is used outside the above-mentioned conditions, he is viewed as the child's father by law, and the social mother has to adopt the child with the donor's consent (while he gives up his legal parenthood).

${ }^{10}$ In Finland, medically assisted reproduction has been legally available to all women since 1997 but has in practice only been available to lesbian couples at (some) private clinics. As of fall 2019, public clinics are also opening up for these couples (Valleala, 2017 and correspondence with Anna Moring, Monimuotoiset perheet (Finland for all families) and Juha Jämsä, Sateenkaariperheet (Rainbow Families Finland).

${ }^{11}$ In October 1999, midwife Nina Stork opened a private infertility clinic in Copenhagen. The clinic, StorkKlinik, offered donor insemination regardless of "the ethnic background, religion, civil status or sexual orientation" of its clients (Nordisk Ministerråd, Nordisk Råd, \& Nordic Committee on Bioethics, 2006, p. 59).

${ }^{12}$ Many go to Denmark to conceive to shorten the wait, to be able to have an anonymous donor, or in order to meet more detailed preferences regarding the donor.

${ }^{13}$ This was possible from 2009 onward (and adopted by a law amendment in June 2008, according to personal communication with Kirsten Sandberg, Institutt for offentlig rett, University of Oslo).
} 
only have two legal parents in the Nordic countries. Starting in December 2019, a child can have more than two (but not more than four) recognized guardians in Finland. ${ }^{14}$ This policy, among other things, helps individuals who have what is referred to as a special and parental-like relationship with a child to spend time with the child and have the child stay with her/him (Lag ang. vårdnad om barn och umgängesrätt 8.2.2019/290). Similarly, in the Netherlands, children might soon be able to have up to four guardians. In the current governmental proposal, non-biological parents are given 'partial custody,' which enables them to take the child to doctor's visits if he/she is sick and to have input on where the child goes to school, among other things (Pieters, www.NLTimes.nl, July 12, 2019).

\section{Male Couples' Transition to Parenthood}

For male same-sex couples, the possibilities by which they can become parents have always been more limited. Although joint adoption is allowed in the countries in focus in this chapter, the waiting lists have been long due to the very low numbers of children put up for within-country adoption and many countries internationally not allowing their children to be adopted by samesex couples. In addition, having a child via surrogacy is controversial and highly debated, although more in some contexts than others. In the Netherlands, commercial surrogacy ${ }^{15}$ is illegal, yet altruistic surrogacy arrangements have been possible for different-sex couples under strict conditions since 1997 (Vlaardingerbroek, 2003). The surrogate should be someone known to the prospective parents, as they are not allowed to advertise for a surrogate. However, until January 2019, same-sex couples did not have access to highly technological surrogacy, which means that both the egg and sperm were donated and carried by a third person.

In the Nordic countries, surrogacy is either illegal or unregulated. All Nordic countries prohibit fertility treatment if the woman receiving the treatment is planning to give the child up for adoption, although this was not legally regulated in Denmark and Finland until 1997 and 2006, respectively (SOU, 2016:11). Today, commercial surrogacy (i.e., paying more than medical costs to a surrogate mother) is illegal in Denmark and Finland, and

\footnotetext{
${ }^{14} \mathrm{~A}$ legal guardian is not the same as a legal parent, even though the roles may overlap.

${ }^{15}$ Altruistic surrogacy occurs when a surrogate carries a child with no additional compensation other than reimbursement for medical costs and other reasonable pregnancy-related expenses. She should also be personally known to the prospective parents. Commercial surrogacy is when a surrogate is compensated for her services beyond such expenses. Commercial surrogacy also includes surrogates offering their services openly or parents openly announcing for the services.
} 
if the court finds that a couple has used a commercial surrogate, it may result in the adoption not being granted to the non-biological parent. ${ }^{16}$ Swedish and Norwegian legislation does not prohibit paying for a surrogate but at the same time does not provide any legal framework for this type of arrangement (SOU, 2016:11). Hence, for Swedish and Norwegian couples, paying for surrogacy in another country is not illegal, and this has helped registered partner/married gay couples — not the least if they are fairly well off- to become parents (see Malmquist \& Spånberg Ekholm, 2020, for Sweden). If the surrogacy arrangement took place abroad, then the paperwork (including the migration of the child) may leave the child without a legal parent or recognized guardian in the country for a while (SOU, 2016:11). Shared parenthood may be easier to realize, and it is not uncommon for male couples to privately arrange for and have children with another couple or a single woman. Again though, in the countries discussed herein, a child can have only two legal parents.

\section{Number of Children Less Than One Year of Age in Same-Sex Couples in Five Countries}

In the following section, graphs are presented that show the number of children zero years of age in female and male same-sex couple households in the countries in focus. The graphs are based on population register data from each country. ${ }^{17}$ They start in the year that the union formation of same-sex couples was legally recognized or when cohabiting same-sex couples with children can be identified in the data. ${ }^{18}$ Cohabiting couples have been included since 1990 in the Netherlands and since 2009 in Norway, and female cohabiting couples have been included since 2005 in Sweden. It is worth noting that the size of the populations in these countries differs considerably. The Netherlands has the largest population (17 million in 2017) and here we also see the largest number of female couples transitioning to parenthood (Fig. 16.1). The trend starts before registered partnership was legally recognized, and it does not

\footnotetext{
${ }^{16}$ In all four Nordic countries, a woman who gives birth is considered to be the child's legal parent and, if she is married to a man, her husband is considered to be the legal father. Hence, achieving joint parenthood through adoption by a social parent requires the surrogate mother's consent. If she is in a heterosexual marriage, her husband also needs to consent. If none of the parents-to-be are the biological parents, then the couple needs to jointly adopt the child.

${ }^{17}$ Data was delivered from Statistics Denmark, Statistics Finland (Statistikcentralen), Statistics Norway (SSB) and Statistics Sweden (SCB). In addition, data from Statistics Netherlands was used.

${ }^{18}$ As legal changes that recognize same-sex couples and parents make them easier to identify in the data in the later years, we most likely underestimate the number of children more so in the earlier than in the later years.
} 


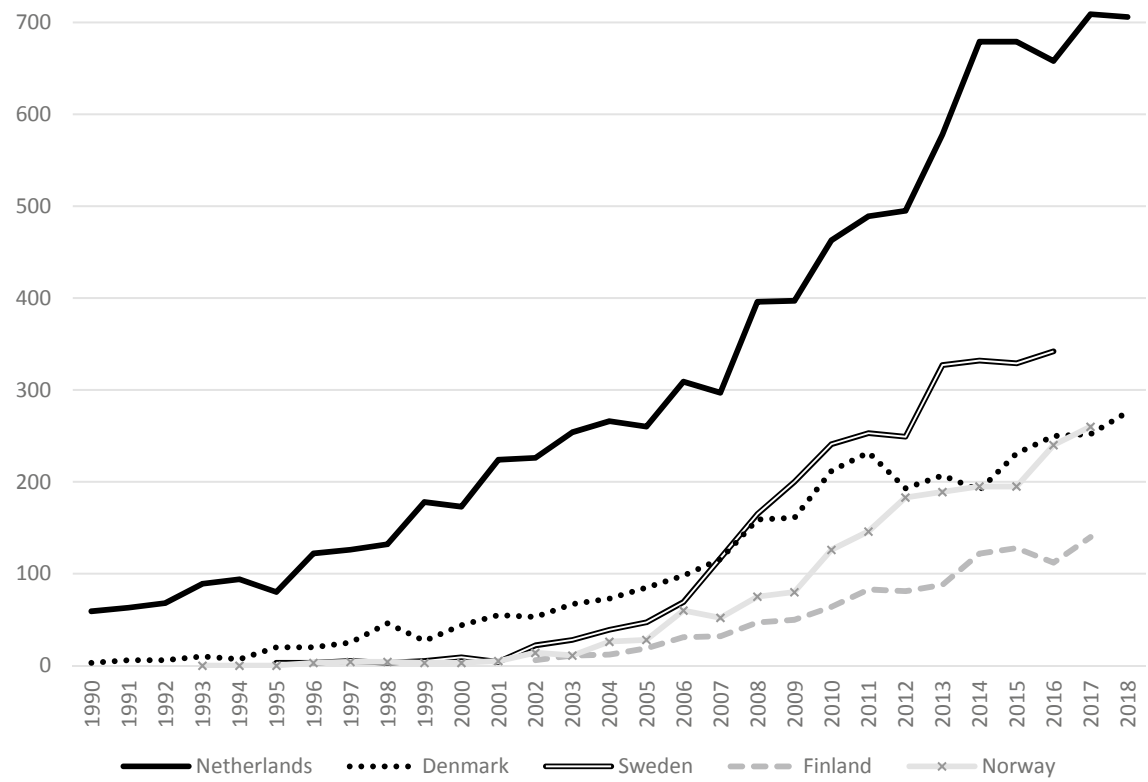

Fig. 16.1 Number of infant children (zero years old) in households with a female same-sex couple (Note Due to data limitations, only couples who are in registered partnerships or are married can be identified in Denmark and Finland. In Sweden [from 2005], Norway [from 2009] and the Netherlands [from 1990] cohabiting couples can be identified and are thus included in the figure)

seem to be affected by legal changes. In 2018, 700 children less than one year of age were living with two mothers. In Denmark, which was the first country to legalize registered partnerships in 1989, a slow but steady increase in the number of (new) children in lesbian couples can be noted, mainly since 1995. Second-parent adoption became possible starting in 1999 and from 2007 onward, when MAI/IVF was (again) possible in public clinics, we see a more rapid increase in the number of children. For Sweden, there has been a clear increase in the couples transitioning to parenthood since 2002; this is particularly true from 2005 onward, when MAI/IVF was made available to lesbian couples. Sweden has a larger population than that of Denmark, Finland, and Norway (10 million compared to approximately 5.5 million in 2016), and this may explain the steeper increase in the number of children less than one year of age in Sweden. Norway legalized registered partnerships early (1993) but did not allow MAI/IVF for lesbian couples until 2009, after which we see the trend for Norway catch up with the numbers for Denmark. In Finland, the increase in the number of children less than one year of age starts later (registered partnerships were legalized in 2002), and it is similar to the trends in the early periods for both Denmark and Sweden. It is worth 


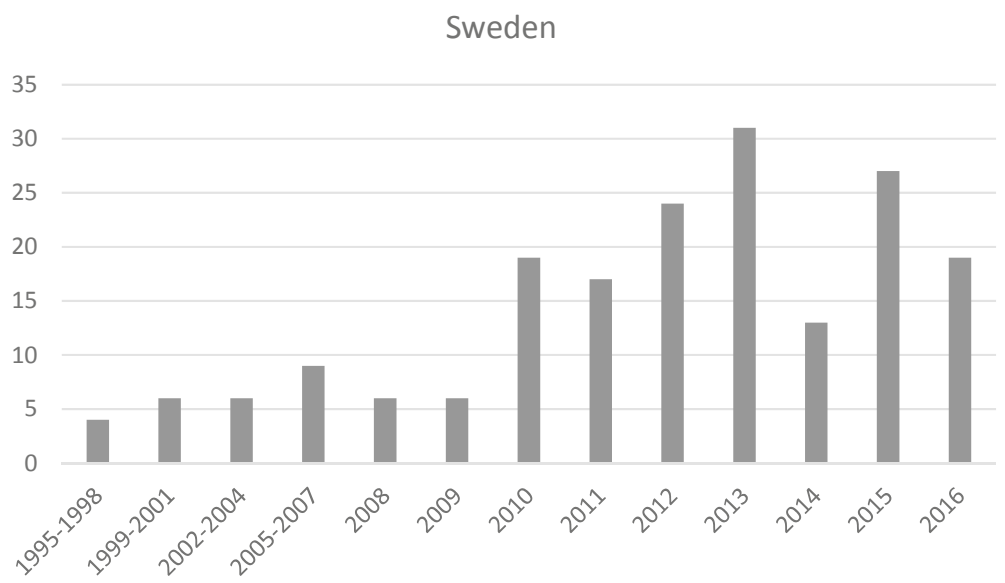

Fig. 16.2 Sweden: number of infant children (zero years old) in households with a male same-sex couple who are married or in a registered partnership

noting that in Finland, MAI/IVF was not available to lesbian couples in all clinics during the period covered. This may explain the more modest increase in the number of couples becoming parents. Due to the inequalities this has caused and based on threats of financial sanctions for discrimination, public health care and fertility centers are increasingly opening up to lesbian couples and single women (as of fall 2019). ${ }^{19}$

In Figs. 16.2, 16.3, and 16.4, the number of children less than one year of age in male same-sex couple households in Sweden, Denmark and Norway are presented. Not surprisingly, the number of male couples transitioning to parenthood is much smaller than the number of female couples transitioning to parenthood in these countries (compare the $y$-axes in Figs. 16.1, 16.2, 16.3, and 16.4). ${ }^{20}$ Sweden and Norway have notably larger numbers of male couples with children than that of Denmark, while in Finland, we identify too few male couples to be able to present a graph. ${ }^{21}$ Denmark and Finland are also the countries with the most restrictive legislation on surrogacy, which is a common way for male same-sex couples to have children. For the Netherlands (Fig. 16.5), we again find a number of gay couples living with a child less than

\footnotetext{
${ }^{19}$ Personal communication with Anna Moring, Monimuotoiset perheet, Finland.

${ }^{20}$ Due to data restrictions, we cannot report on years when fewer than three couples make up the bar charts. Consequently, we use bars that are accumulated for some years.

${ }^{21}$ Very few male same-sex couples where both fathers were legally recognized as parents can be found in the data for Finland. The low number has been confirmed by Sateenkaariperheet (Rainbow Families) Finland. Some additional couples in which one of the partners became a biological father but where the child cannot be identified as living in the household can be observed but are not included in the graph.
} 


\section{Denmark}
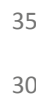

25

20

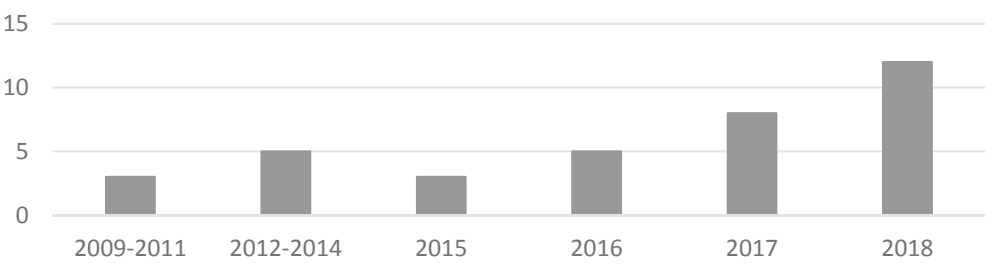

10

5

0

35

30

5

20

Fig. 16.3 Denmark: number of infant children (zero years old) in households with a male same-sex couple who are married or in a registered partnership



Fig. 16.4 Norway: number of infant children (zero years old) in households with a male same-sex couple who are in a registered partnership, married or cohabiting (from 2009)

one year of age from the start of the observation period in 1990 onward. Nevertheless, the number of Dutch male couples living with a child below one year of age has been smaller than that in Sweden in more recent years, most notably since 2010 (cf. Fig. 16.2). ${ }^{22}$ The difference may be explained by more male couples having children and sharing parenting with single women

\footnotetext{
${ }^{22}$ Given that very few couples have been able to jointly adopt a child, we do not think that we lose a lot of adoptive couples due to the age restriction applied in the graphs.
} 


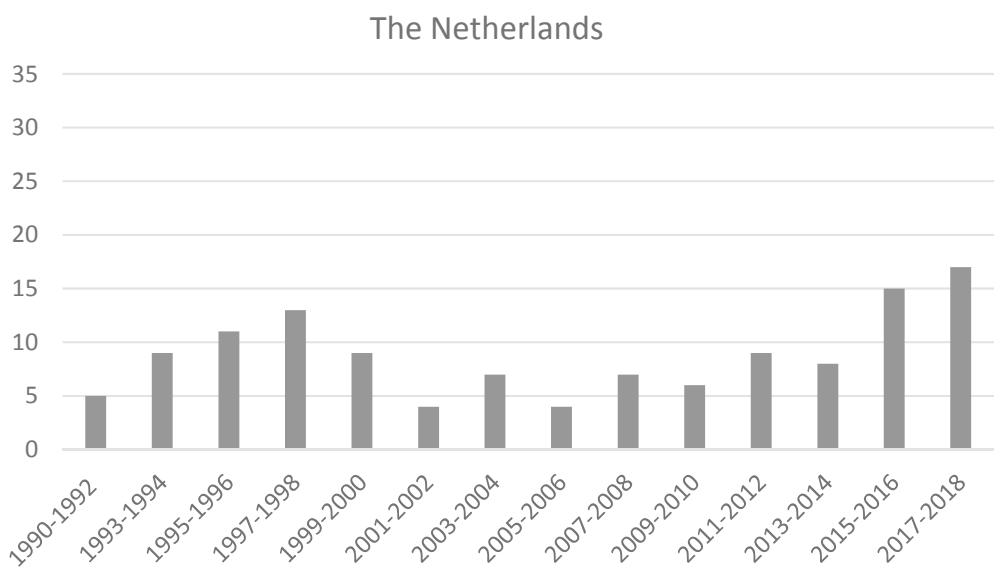

Fig. 16.5 The Netherlands: number of infant children (zero years old) in households with a male same-sex couple who are cohabiting, married or in a registered partnership

or lesbian couples in the Netherlands. In the figures discussed here, as well as those seen in Fig. 16.1, we cannot identify children who partly live in the household if they are registered at another address.

\section{Parentalization in Practice. Part 2: Sharing the Care of the Child}

\section{Family Leave Rights}

In this section, we discuss same-sex couples' family leave rights and the extent to which they have differed during periods — if at all_-from the rights of different-sex couples. This exploration enables an understanding of the second step of the parentalization process, namely, the ability of both parents (or more than two parents) to make use of family policies and share any jobprotected and potentially subsidized leave to care for a child. As a basis for the comparison, we provide information on parental leave policies in separate fact boxes. This information often stems from the yearly reports from the International Network on Leave Policies and Research (see: www.leavenetwork.org). We use the terminology applied in the reports (based on the concepts used in laws and policies). For instance, this means that paternity leave would be the leave assigned to the social mother in a female same-sex couple. In addition to the publicly funded family leave policies in the various countries, many parents are covered by collective employer agreements that give them a higher 
wage replacement than that which they receive by public social insurance. This means that the income obtained during leave for many is higher than the earlier earnings levels presented in the fact boxes.

Although we generally think of the legal recognition of same-sex parenthood as the first step towards family formation and the practical prerequisites of sharing the care of the child as the second step, this has not been the sequence of events in Sweden. Ever since the right to registered partnership was introduced in 1995, biological parents have been able to share parental leave with a registered partner/married spouse. In other words, if, for instance, a lesbian couple privately arranges for and becomes pregnant in partnership with a gay couple (i.e., there is one biological mother and one biological father who want to be active parents jointly with two social parents), then the biological parents can sign over parental leave days to their partners such that, in total, four parents can share leave for the child if both biological parents are in registered partnerships/married (but not to each other). Parental leave is linked to the child in Sweden and in our example, the total leave time that the four parents can share will be the same as that for a two-parent family.

In Norway, the ability to share parental leave was not linked to registered partnership, marriage or adoption but was granted to same-sex couples in separate legislation in 2007 (Table 16.1). In Denmark, legal parenthood and access to family policies did not coincide. When MAI/IVF was made available to lesbian couples in all clinics in 2007 (it had been available in private clinics since 1999), it was framed as a health law rather than a family law (Jeppesen de Boer \& Kronborg, 2012). As such, it was more influenced by health equality principles than by family law and parental rights. This meant that same-sex and adoptive parents could not share parental leave until the Maternity Act was revised in 2009 (Tølbøll, 2014). In Finland, starting in 2007, the registered partner of the birth mother had the right to parental leave if the child was born after the registered partnership started and if the social mother was living with the child and the child's legal parent (Valleala, 2017). In 2017, the law was changed so that a woman who gives birth can share her parental leave with a partner regardless of their gender and civil status. However, biological fathers do not have the same option.

\section{Family Leave in Sweden}

Same-sex couples who are married or in registered partnership have been able to share family leave in Sweden since registered partnership was introduced in 1995. When same-sex parenthood was legally recognized in 2003, the number of female couples transitioning to parenthood started growing. At this time, parents had the right to 480 days of parental leave with a child, 
which could be shared between the parents, with 60 days being reserved for each parent. ${ }^{23}$ Since 2016, 90 days have been reserved for each parent. For 390 of the 480 days, the reimbursement is approximately $80 \%$ of the previous earnings, up to a ceiling. In addition, the remaining 90 out of the 480 days are reimbursed at a lower flat rate. Parents also have the right to temporary parental leave at the time of birth, which consists of ten days for the parent not giving birth, to be used within 60 days of delivery. Those who have worked less than 240 days before the expected delivery or who have had a low daily income during this period receive the low flat rate during the entire leave period. When parents adopt a child, they get the same parental leave insurance (in terms of days and benefits) as parents who have a biological child.

Sources Chronholm (2005), Duvander and Haas (2018), Korsell and Duvander (2019).

One group that may have difficulties using parental leave are male couples who have become parents with the help of a surrogate abroad. The migration and adoption process may take time and consequently, the child may be without a legal parent in the country for months. For example, in Sweden, when the surrogacy mother is not a citizen, then she cannot make use of the parental leave system and neither can she sign over leave to the fathers. Instead, the fathers may need to use vacation time or leaves of absence to stay home with the baby (Malmquist \& Spånberg Ekholm, 2020). This differs from Dutch parental leave regulations that enable a person to take leave for a prospective adoptive child (as well as for a foster child and a step-child), as long as the child is registered at the same address as the person taking the leave (Rijksoverheid, the Netherlands, downloaded on 14.2 2020). In Denmark, only those who are legally recognized as the parents of the child can make use of family leave. Second-parent adoption rules complicate things for some couples due to the 2.5 years that the parent must live with the child before s/he can adopt (see Table 16.1). This policy mainly affects lesbian couples who have not conceived at a clinic and male couples in which one of the partners is the biological father. The rules are similar in Norway, with a few exceptions. First, second-parent adoption can take place after the parent has lived with the child for five years (unless the child was conceived through $\mathrm{MAI} / \mathrm{IVF}$ at a clinic). Second, if only one legal parent has parental responsibilities or if there are two legal parents but one parent is not using leave, then the spouse (if any) of the legal parent with parental responsibilities may use unpaid family leave from work (but not parental leave benefits) (Eeg, 2017).

\footnotetext{
${ }^{23}$ This assumes two-parent families and that the reserved days are for the two legally recognized parents. If there are additional social parents, no days are reserved for them (even though they may take leave).
} 
In Finland, only a few gay couples have attained legal parenthood status for both partners after second-parent adoption was made possible in 2009 and have thus been able to both take parental leave.

\section{Family Leave in Denmark}

MAI/IVF has been available to female same-sex couples since 1999 in private clinics and since 2007 in all clinics (apart from the period of 1992-1997 when it was also available). However, it was not until 2009, with the revision of the Maternity Act (Barselsloven), that same-sex parents and adoptive parents were able to share parental leave (Tølbøll, 2014). The maternity leave insurance covers 18 weeks, specifically, four weeks before and 14 weeks after birth. Paternity leave is two weeks. Parental leave is 32 weeks and can be used until the child is 48 weeks of age. Parental leave is individual; each parent can claim at most 32 weeks of leave, but the total cash benefit of parental leave per family cannot exceed 32 weeks (excluding maternity and paternity leaves). The benefit levels of maternity, paternity, and parental leaves were $90 \%$ of the previous earnings up to a ceiling in the beginning of the period, and a cash benefit of at most approximately 580 EUR per week before taxes at the end of the period (the benefit cannot exceed the previous earnings). Adoptive parents have the same leave rights as other parents, with the exception that two of the total 48 weeks need to be taken by both parents jointly. Eligibility for leave is conditional on the parent working at least 120 hours in the 13 weeks preceding the leave.

Sources Rostgaard (2009), Bloksgaard and Rostgaard (2019).

\section{Family Leave in Norway}

Starting in 2007, a social mother in a female same-sex couple could share the parental leave with the birth mother given that she was recognized as the parent of the child at the start of the leave. ${ }^{24}$ At that time, parents could share either 29 weeks ( 49 weeks as of 2018) of leave at $100 \%$ of the earlier income or 39 weeks (59 weeks as of 2018) at $80 \%$ of the previous income up to a ceiling, of which six weeks (ten weeks as of 2018) were reserved for each parent and three weeks (svangerskapspermisjon) needed to be taken before the birth. To be eligible for the earnings-related benefits, the parent needs to have been employed (or self-employed) for six of the last ten months prior to the birth and to have earned at least a given minimum amount of income during the previous year. Those not eligible receive a flat rate payment. A paternity leave of two weeks after the birth is unpaid by the government. Adoptive parents get the same amount of leave as couples in which one has given birth to the child, with the exception of the svangerskapspermisjon (the three weeks reserved for before a birth).

Sources Brandth and Kvande (2007, 2018), Eckhoff Andresen and Nix (2019), Eeg (2017). 


\section{Family Leave in Finland}

Since 1997, lesbian couples have had access to assisted reproduction techniques in private clinics in Finland. Since 2007, due to a change in the Health Insurance Act, the birth mother's spouse or partner has had access to parental leave entitlements (Valleala, 2017). In 2002, when registered partnership was introduced, maternity leave consisted of 105 working days (a work week was defined as six days), of which 30-50 days must be taken before the birth. Paternity leave consisted of 18 working days, and parental leave consisted of 158 working days per family. Leave benefits were earnings related, averaging $66 \%$ of the previous earnings.

As of 2017, a woman who gives birth can share her parental leave with a partner regardless of gender (biological fathers do not enjoy this option). During the first 56 days of the 105 days of maternity leave, the payment is $90 \%$ of the annual earnings up to a ceiling; after this point, the payment is $70 \%$ of the earnings (as of 2018). Entitlement is linked to residence and is paid to all who have lived in Finland (or have been insured in another EU member state) for at least 180 days before the birth. Mothers who are not employed or who have low annual earnings receive a minimum flat-rate benefit. As of 2018, paternity leave consists of 54 working days, and both paternity and parental leave (the latter consists of 158 working days, as of 2018) are reimbursed at $70 \%$ of the previous earnings. The adoptive parents of a child younger than seven years of age but older than 2 months of age are eligible to 200 working days of leave (234 if the child is younger than 2 months old).

Sources Salmi and Lammi-Taskula (2005), Salmi, Närvi, and Lammi-Taskula (2018).

In the Netherlands, maternity, paternity and parental leaves are for employees only. Birth mothers and their partner or the person acknowledging the child are eligible (Rijksoverheid, the Netherlands, downloaded on 14.2 2020). Unlike the other countries in this chapter, parental leave is strictly personal and cannot be signed over. This means that single parents have only 26 weeks of leave in total, whereas couples have 52 weeks. Leave is linked to legal parenthood (or acknowledgment of the child, see the fact box). When a child has more than two adults who share parenting roles, then the persons who are not legally recognized as parents cannot take parental leave.

\footnotetext{
${ }^{24}$ In 2007 , the law was changed so that a person who adopts the child of their same-sex partner can use parental leave. Leave could also be taken by a married spouse of the birth mother if there was no other legal parent or if this parent was not using leave. In 2006, the Norwegian government changed the interpretation of the guidelines for second-parent adoption (Q-1045) so that if the child was conceived at a clinic using a non-anonymous donor, then the adoption process could start directly after childbirth. However, between 2002 and 2006, this principle was already being used by some regions and case workers due to unclarity in the original guidelines. Sources Barne-, likestillingsog inkluderingsdepartementet $(2006,2016)$ and correspondence with Martin Eckhoff Andresen and Kirsten Sandberg. The new directives from 2006 can be found here: https://www.aftenposten.no/ norge/i/G3pn9/Brev-om-stebarnsadopsjon.
} 


\section{Family Leave in the Netherlands}

Parental leave was introduced in 2001 in the Netherlands, which was the same year that same-sex marriage and within-country adoption were legalized, and it immediately became available to different-sex as well as same-sex couples. Birth mothers have 16 weeks of fully paid maternity leave, which is regulated by the national government. All female employees have the right to maternity leave, and those who are self-employed are compensated up to the minimum wage. Paternity leave is fully paid for five days, and as of July 1, 2020, an additional 5 weeks at $70 \%$ of earlier earnings can be added. This leave is granted to the employed partner of the birth mother or a person acknowledging the child. The birth mother and her partner can each take unpaid parental leave up to 26 times their weekly work hours per child. In 2018, adoptive parents had four, and since 2019, they have six weeks of leave with payment equivalent to maternity leave. Adoptive parents have the same parental leave rights as other parents.

Sources Den Dulk (2018), Nikolina (2017b).

\section{Parentalization: Summary and Conclusion}

In this chapter, we present the concept of parentalization. Parentalization is defined as the ability to become a parent and be recognized as such, both legally and via social policies. The concept aims to address a gap in the welfare, social policy, and gender regime literature. A key concept in this literature is defamilialization and the extent to which women can be freed from economic dependency on a spouse and covered by social policies when performing care work in the household. The contributions made by researchers engaging with this concept have been imperative in regard to mapping gender inequalities in welfare states. The concept problematizes dependencies and imbalances in heterosexual couples and families but is not applicable to the same extent to other family constellations. One group that faces varying degrees of difficulties regarding (i) being legally recognized as parents and (ii) making use of family policies in various contexts is same-sex couples. In this chapter, we focused on five countries that were among the first to legally recognize same-sex parenthood: the Netherlands, Denmark, Finland, Norway, and Sweden. By mapping the road to legal parenthood and family policy rights for same-sex couples in these countries, we identified obstacles and impediments on the road to parentalization. We also provided evidence of the importance of legal, parental, and policy rights for the transition to parenthood among female and male same-sex couples by graphing the increase in the number of registered partnered/married couples with a child 
less than one year of age in the study nations. Even if many such couples transitioned to parenthood before same-sex partner and marriage rights were in place (though we are unable to fully map this with the data at hand), the legal recognition of parenthood came with increased certainty and security in the couples' everyday lives, as well as in case of parental separation or divorce. In the following, we sum up and discuss some of the hurdles to full parentalization that same-sex couples have had to overcome and/or to some extent are still facing in the nations focused on in this study.

Starting with the ability to transition to parenthood and be legally recognized as parents, same-sex couples still face legal obstacles to parenthood in many countries. In the countries discussed in this chapter, many obstacles have been removed, but it remains difficult for some to attain parenthood. This leads us to the conclusion that the first prerequisite (i) is to some extent fulfilled, at least for female couples. In practice, the number of possible routes to parenthood differs for same-sex couples compared to different-sex couples. Very few same-sex couples have been able to jointly adopt a child, as adoption rates have decreased (Mignot, 2019) and many countries and adoption agencies are reluctant to put children up for adoption by same-sex parents. These issues have made it difficult for male couples to realize their (any) parenting desires. Another example is the marriage presumption that applies to different-sex but not same-sex parents in many countries. Sweden is one example, where a married social mother is not recognized as the child's parent from birth but must go through a bureaucratic process (the same as that for cohabiting different-sex fathers), in order to be recognized as a legal parent of her child. In Finland, MAI/IVF was not available to lesbian couples in all clinics until recently. Private clinics are often more expensive than public clinics (as costs are more often subsidized in the latter). After threats of financial sanctions based on the discrimination, starting in the fall 2019, public clinics in Finland have been increasingly opening up to lesbian couples and single women.

Turning to the second criteria (ii), some family policies may enable samesex parents to share in the care of a child in the same way as that of different-sex couples, while some may not. In Denmark, there was a delay between providing lesbian couples with MAI/IVF in public clinics and granting both parents with policy rights to take parental leave with the child. In Sweden, same-sex parents who were registered as partners could share parental leave even before they were legally recognized as parents, as parental leave is linked to marriage and cohabitation. Today, legally recognized samesex parents have the same family leave rights as different-sex couples have in all the countries in focus. However, whereas a woman who gives birth 
can share the leave with a partner independent of gender and civil status in Finland, biological fathers does not have the same option. In addition, second-parent adoption rules may delay parental leave use or render it impossible to use in time in Denmark and Norway, where a non-biological parent needs to wait 2.5 and 5 years, respectively, before they can adopt the child, if the child is not conceived through MAI/IVF at a clinic.

As indicated above, parentalization is more readily available to some samesex couples than others. We argue that this partly reflects the dominant norms on gender and motherhood. Married female couples face fewer barriers to parentalization than other couples do. This is not only linked to the partners' ability to become pregnant and carry a child. We argue that part of the reason is also that female couples more closely resemble the heteronormative family. Ideals about a child's need of a mother are strong, and women are expected to want to have children and to be more child-oriented and better caretakers than men (e.g., Grunow \& Evertsson, 2016, 2019). This expectation is partly mirrored in family leave policies where paternity or co-parent leaves are often short and seldom paid (the Netherlands being the obvious example in our case). In addition, the topic of surrogacy is highly debated, with many advocating the rights of women not to be exploited by any form of surrogacy, whereas others are less critical to altruistic surrogacy compared to commercial surrogacy (cf. Baker, 1996; Roach Anleu, 1990). Commercial surrogacy is not legal in any of the countries in focus in this chapter. However, the degree to which it is legally punished varies and partly seems to influence gay couples' abilities to become parents. Examples include Sweden and Norway, where surrogacy is not legally regulated for those who go abroad, which seems to contribute to a larger increase in gay parenthood in these countries (cf. Malmquist \& Spånberg Ekholm, 2020; see also Figs. 16.2 and 16.4). Currently, altruistic surrogacy is allowed in the Netherlands, and it seems more accepted (although it is still not legally regulated) in Denmark than in the other Nordic countries, as indicated by media coverage. ${ }^{25}$ Studies analyzing the practices that surround the surrogacy process in countries that ban commercial surrogacy, in countries that allow altruistic surrogacy, and in countries without surrogacy regulations would enable a more informed discussion about the pros and cons-and intended and unintended consequences - of various laws and regulations for parents(-to-be) and surrogates, as well as children.

\footnotetext{
${ }^{25}$ Examples are CPH Post Online: http://cphpost.dk/?p=86936, DR.dk: https://www.dr.dk/nyheder/ indland/overblik-maa-man-bruge-rugemor-i-danmark-her-er-reglerne, both downloaded on September 13, 2019.
} 
Even if male same-sex couples have greater difficulties in becoming parentalized than do female same-sex couples, the former still find it easier to fit the definition of a family than do other groups such as single gay fathers or multi-parent families (e.g., Carroll, 2018; Downing, 2013). Hence, the analyses and discussions in this chapter only scratch the surface in regard to parentalization in a broader range of couples and families. In the countries in focus in this chapter, a child can only have two legal parents; thus, any social parents in a multi-parent family are not recognized by law. However, even in this context, we see signs of change in the Netherlands, where children soon should be able to have up to four guardians, and in Finland, where a child can have three or possibly four guardians, as decided by the court. These are important advances that will influence not only so-called pink or rainbow families but also heterosexual, step- and bonus-parent families. Facilitating for the latter families was also one of the main motives spurring these changes.

Another group of families that can be analyzed in terms of parentalization is that of single-parent families. As indicated above, in the Netherlands, parental leave rights are individual. For single parents, this may mean that they may be forced to send the child to day care earlier than hoped for, or it may force them to drop out of paid work altogether. In this case, the second part of parentalization, i.e., the access to parental leave rights, is in place, but in practice, such access produces inequalities for children based on family type and it complicates for some parents to realize their parenting and care ideals. Another group of parents that can be analyzed within the parentalization concept are couples in which one or both partners have migrated. The extent to which both partners can share legal parenthood and care via social policies, as well as any waiting periods prior to the time when such sharing is realized in various contexts, could efficiently be mapped using the parentalization concept. Here, we can think of different potential problems linked to whether the couple is married or not, whether the birth mother (if any) or the other parent is a citizen or not, or whether they have both migrated. Lesbian couples who migrate to Sweden risk losing their joint legal parenthood due to a Swedish law stipulating that the social mother can only be the parent from birth if the child was inseminated either at a Swedish clinic ormore recently — at a foreign, certified clinic using a non-anonymous donor. Focusing on couples that migrate no doubt adds layers of complexity in terms of parentalization that we have not dug into at all in this chapter. Hopefully though, our first attempt to establish and apply the concept will spur such analyses. 
Parentalization, which is the ability to (i) transition to parenthood and (ii) make use of family policies and share the care of the child, varies considerably between countries and groups of parents, even when we focus on five countries that are at the forefront in regard to same-sex couples' legal rights to marry and have children. Lurking in the background are norms linked to the heterosexual family ideal, to motherhood and fatherhood, making parentalization more or less challenging for the groups of parents who do not fit within the regular mold. Future empirical research of same-sex couples could study patterns of fertility and parity and possible inequalities within this group, for instance, by family type or by family income. By mapping out and understanding how the transition to parenthood and the process of parentalization work for same-sex couples, we can evaluate how countries either reproduce normative systems or become more inclusive by going beyond the heteronormative family.

Grant Acknowledgements This research has received funding from the European Research Council (ERC) under the European Union's Horizon 2020 research and innovation program awarded to Marie Evertsson (grant agreement No. 771770).

Other Acknowledgments We would like to thank a number of researchers and country experts for responding to questions on short notice, as well as for providing us with comments and suggestions on the text. Among them are Martin Eckhoff Andresen, Peter Fallesen, Jennifer Hook, Juha Jämsä, Anna Malmquist, Anna Moring, Michael Nebeling Petersen, Nicole Ovesen, Tine Rostgaard, Kirsten Sandberg, Tone Sverdrup, Aslak Syse and Hannah Zagel. Any remaining errors or mistakes are on us. We have also benefitted from comments and suggestions from participants at the conference Towards Resilient Nordic Welfare States-Challenges, Responses and Consequences in Helsinki in March 2019 and the Community, Work and Family in Diverse Contexts and Changing Times conference in Malta in May 2019. Finally, we are also grateful to the research group at the social policy unit at SOFI, Stockholm University for providing us with comments and suggestions, especially Kenneth Nelson and Sebastian Sirén.
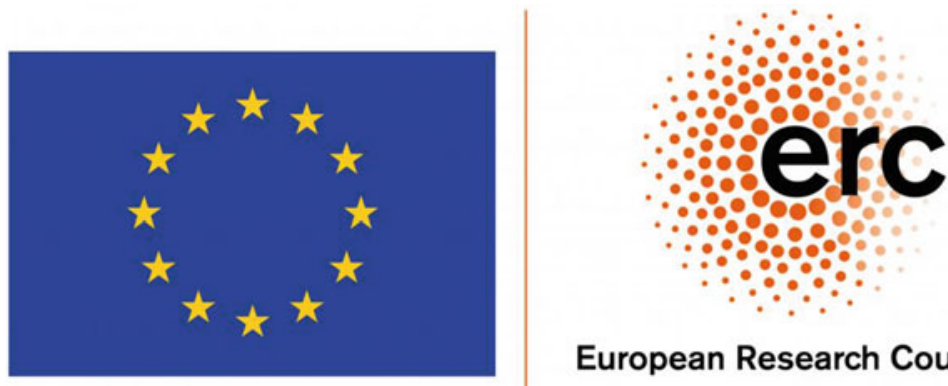

European Research Council

Established by the European Commission 


\section{References}

Aldén, L., Björklund, A., \& Hammarstedt, M. (2017). Early health and school outcomes for children with lesbian parents: Evidence from Sweden. IZA, DP No. 10616.

Baker, B. M. (1996). A case for permitting altruistic surrogacy. Hypatia, 11(2), 3448.

Barne-, likestillings- og inkluderingsdepartementet. (2006). Ot.prp. nr. 5 (20062007) Om lov om endringer $i$ folketrygdloven (rett til foreldrepenger ved tidlig stebarnsadopsjon). Retrieved from https:/www.regjeringen.no/no/dokumenter/ otprp-nr-5-2006-2007-/id430437/?ch=1.

Barne-, likestillings- og inkluderingsdepartementet. (2016). Q-1045/revidert 2016 Saksbehandling ved søknad om innenlands- og utenlandsadopsjon. Retrieved from https:/www.regjeringen.no/contentassets/5ce3f221d6944d4f818203f4672 5f182/q-1045-sist-revidert-av-bld-mars-2016-419126.pdf.

Berg Hulthén, V., \& Nordqvist, A. (2017, December 19). Surrogat. Att bli och vara förälder. Retrieved from https:/www.rfsl.se/familj/att-bli-och-vara-foralder/ surrogat/.

Bloksgaard, L., \& Rostgaard, T. (2019). Denmark country note. In A. Koslowski, S. Blum, I. Dobrotić, A. Macht, \& P. Moss (Eds.), International review of leave policies and research. Retrieved from http://www.leavenetwork.org/lp_and_r_repo rts/.

Brandth, B., \& Kvande, E. (2007). Norway. In P. Moss \& K. Wall (Eds.), International review of leave policies and related research 2007. Department for Business Enterprise \& Regulatory Reform, Employment Relations Research Series No. 80. Brandth, B., \& Kvande, E. (2018). Norway. In S. Blum, A. Koslowski, A. Macht, \& P. Moss (Eds.), 14th International review of leave policies and related research 2018. Retrieved from https://www.leavenetwork.org/annual-review-reports/archive-rev iews/.

Carroll, M. (2018). Managing without moms: Gay fathers' incidental activism and the politics of parental gender. Journal of Family Issues, 39(3), 3410-3435.

Chronholm, A. (2005). Leave policies and research Sweden. In F. Deven \& P. Moss (Eds.), Leave policies and research: Reviews and country notes. Brussels: Centrum voor Bevolkings- en Gezinsstudie (CBGS).

Dalager Kjaer, L. (2017). Betydningen af gældende ret for nye samfundsstrukturer i familiemæssig henseende. Retsvidenskabeligt Tidsskrift (RETTID). Retrieved from https://law.au.dk/fileadmin/Jura/dokumenter/forskning/rettid/ Afh_2017/afh14-2017.pdf.

Den Dulk, L. (2018). The Netherlands. In S. Blum, A. Koslowski, A. Macht, \& P. Moss (Eds.), International review of leave policies and research 2018. Retrieved from http://www.leavenetwork.org/lp_and_r_reports/. 
Downing, J. B. (2013). Transgender-parent families. In A. Goldberg \& K. R. Allen (Eds.), LGBT-parent families: Innovations in research and implications for practice (pp. 105-115). New York, NY: Springer.

Duvander, A.-Z., \& Haas, L. (2018). Sweden. In S. Blum, A. Koslowski, A. Macht, \& P. Moss (Eds.), International review of leave policies and research 2018. Retrieved from http://www.leavenetwork.org/lp_and_r_reports/.

Eckhoff Andresen, M., \& Nix, E. (2019). What causes the child penalty? Evidence from same sex couples \& policy reforms (Statistics Norway, Discussion Papers 902).

Eeg, T. (2017). Parenting and legal family formats in Norway. In K. Waaldijk et al. (Eds.), The LawsAndFamilies database-Aspects of legal family formats for same-sex and different-sex couples. Paris: INED. Retrieved from www.LawsAndFamilies.eu.

Esping-Andersen, G. (1990). The three worlds of welfare capitalism. Cambridge: Polity Press.

Esping-Andersen, G. (1999). Social foundations of postindustrial economies. Oxford: Oxford University Press.

Eydal, G. B., Gíslason, I. V., Rostgaard, T., Brandth, B., Duvander, A. Z., \& LammiTaskula, J. (2015). Trends in parental leave in the Nordic countries: Has the forward march of gender equality halted? Community, Work \& Family, 18(2), $167-181$.

Frantzen, T. (2011). National report: Norway. American University Journal of Gender Social Policy and Law, 19(1), 273-276.

Grunow, D., \& Evertsson, M. (Eds.). (2016). Couples' transitions to parenthood: Analysing gender and work in Europe. Northampton, MA: Edward Elgar.

Grunow, D., \& Evertsson, M. (Eds.). (2019). New parents in Europe: Work-care practices, gender norms and family policies. Northampton, MA: Edward Elgar.

Haas, L., \& Rostgaard, T. (2011). Fathers' rights to paid parental leave in the Nordic countries: Consequences for the gendered division of leave. Community, Work \& Family, 14(2), 177-195.

Harris, E. C., \& Estevez, M. L. (2017). The role of gender and motherhood ideologies in perpetuating workplace inequality. Journal of Research in Gender Studies, $7(2), 67-85$.

Jeppesen de Boer, C. G., \& Kronborg, A. (2012). National report: Denmark. American University Journal of Gender, Social Policy \& the Law, 19(1), 5.

Keck, W., \& Saraceno, C. (2013). The impact of different social-policy frameworks on social inequalities among women in the European Union: The labour-market participation of mothers. Social Politics, 20(3), 297-328.

Korpi, W. (2000). Faces of inequality: Gender, class, and patterns of inequalities in different types of welfare states. Social Politics, 7(2), 127-191.

Korpi, W., Ferrarini, T., \& Englund, S. (2013). Women's opportunities under different family policy constellations: Gender, class, and inequality tradeoffs in western countries re-examined. Social Politics, 20(1), 1-40.

Korsell, N., \& Duvander, A. (2019). Effekter av höjd ersättning i föräldrapenning på grundnivå. En analys av effekter på barnafödande och förvärvsarbete av 
höjd ersättning i föräldrapenningens grundnivå (Rapport 2019:6). Inspektionen för socialförsäkringen.

Lag ang. vårdnad om barn och umgängesrätt 8.2.2019/290. Finlex Data Bank. https://www.finlex.fi/sv/laki/ajantasa/1983/19830361.

Leitner, S. (2010). Germany outpaces Austria in childcare policy: The historical contingencies of 'conservative' childcare policy. Journal of European Social Policy, 20(5), 456-467.

Lewis, J. (1992). Gender and the development of welfare regimes. Journal of European Social Policy, 2(3), 159-173.

Lister, R. (1994). She has other duties: Women, citizenship and social security. In S. Baldwin \& J. Falkingham (Eds.), Social security and social change: New challenges to the Beveridge model. New York, NY: Harvest Wheatsheaf.

Malmquist, A., \& Spånberg Ekholm, A. (2020). Swedish gay men’s pursuit of fatherhood: Legal obstacles and strategies for coping with them. Lambda Nordica, 24(2-3), 53-80.

Mazrekaj, D., De Witte, K., \& Cabus, S. (2019). School outcomes of children raised by same-sex couples: Evidence from administrative panel data. Unpublished manuscript, Leuven Economics of Education Research (LEER). Leuven, the Netherlands.

McGlynn, C. (2001). European Union family values: Ideologies of "family" and "motherhood" in European Union law. Social Politics: International Studies in Gender, State \& Society, 8(3), 325-350.

Mignot, J. F. (2019). Child adoption in Western Europe, 1900-2015. In C. Diebolt, A. Rijpma, S. Carmichael, S. Dilli, \& C. Störmer (Eds.), Cliometrics of the family (pp. 333-366). Cham: Springer.

Misra, J., Budig, M. J., \& Moller, S. (2007). Reconciliation policies and the effects of motherhood on employment, earnings and poverty. Journal of Comparative Policy Analysis, 9(2), 135-155.

Moderskapslag 20.4.2018/253. https://www.finlex.fi/sv/laki/ajantasa/2018/201 80253.

Moore, M. R. (2011). Two sides of the same coin: Revising analyses of lesbian sexuality and family formation through the study of black women. Journal of Lesbian Studies, 15(1), 58-68.

Nikolina, N. (2017a). Parenting and legal family formats in Netherlands. In K. Waaldijk, M. Digoix, N. Nikolina, G. Zago, D. Damonzé, A. Caporali, \& K. Nait Abdellah (Eds.), The LawsAndFamilies database-Aspects of legal family formats for same-sex and different-sex couples. Paris: INED. Retrieved from www. LawsAndFamilies.eu.

Nikolina, N. (2017b). Evolution of parenting rights in Europe-A comparative case study about questions in section 3 of the LawsAndFamilies database. In C. Waaldijk (Ed.), More and more together: Legal family formats for same-sex and different-sex couples in European countries. Comparative analysis of data in the LawsAndFamiliesDatabase. FamiliesAndSocieties WP series 75. 
Nordisk Ministerråd, Nordisk Råd, \& Nordic Committee on Bioethics. (2006). Assisted reproduction in the Nordic countries: A comparative study of policies and regulation (TemaNord 2006:505). Copenhagen: Nordic Council of Ministers.

Orloff, A. S. (1993). Gender and the social rights of citizenship: The comparative analysis of gender relations and welfare states. American Sociological Review, 58(3), 303-328.

Pieters, J. (2019, July 12). Dutch kids can have up to four parents. Surrogates' rights to be set down in law: Report. NLTimes.nl. https://nltimes.nl/2019/07/12/dutchkids-can-four-parents-surrogates-rights-set-law-report.

Reimat, A. (2019). Gendered welfare regimes, work-family patterns and women's employment. In C. Diebolt, A. Rijpma, S. Carmichael, S. Dilli, \& C. Störmer (Eds.), Cliometrics of the family. New York, NY: Springer.

Rijksoverheid, the Netherlands. Downloaded on February 14, 2020. https://www. rijksoverheid.nl/onderwerpen/ouderschapsverlof/vraag-en-antwoord/recht-opouderschapsverlof.

Roach Anleu, S. L. (1990). Reinforcing gender norms: Commercial and altruistic surrogacy. Acta Sociologica, 33(1), 63-74.

Rostgaard, T. (2009). Denmark. In P. Moss (Ed.), International review of leave policies and related research 2009. Employment Relations Research Series No. 102. London: Department for Business Innovation \& Skills.

Salmi, M., \& Lammi-Taskula, J. (2005). Leave policies and research Finland. In F. Deven \& P. Moss (Eds.), Leave policies and research: Reviews and country notes (CBGS-Werkdocument 2005/3). Brussels: Centrum voor Bevolkings- en Gezinsstudie (CBGS).

Salmi, M., Närvi, J., \& Lammi-Taskula, J. (2018). Finland. In S. Blum, A. Koslowski, A. Macht, \& P. Moss (Eds.), International review of leave policies and research 2018. Retrieved from http://www.leavenetwork.org/lp_and_r_reports/.

Saraceno, C., \& Keck, W. (2011). Towards an integrated approach for the analysis of gender equity in policies supporting paid work and care responsibilities. Demographic Research, 25, 371-406.

SOU 2016:11 Olika vägar till föräldraskap: Slutbetänkande av utredningen om utökade möjligheter till behandling av ofrivillig barnlöshet. Stockholm: Wolters Kluwer.

Titmuss, R. M. (1958). Essays on the welfare state. London: Allen and Unwin.

Tølbøll, L. (2014). Family policies Denmark (2014). Population Europe Research Finder and Archive (PERFAR). Retrieved from https://splash-db.eu/.

Valleala, A. (2017). Parenting and legal family formats in Finland. In K. Waaldijk et al. (Eds.), The LawsAndFamilies Database-Aspects of legal family formats for same-sex and different-sex couples. Paris: INED. Retrieved from https://www.ined. fr/Xtradocs/lawsandfamilies/LawsAndFamilies-FI-Section3.pdf.

Vlaardingerbroek, P. (2003). Draagmoederschap: een gecompliceerde constructie. Ars Aequi, 3, 171-179.

Waaldijk, K. (Ed.). (2017). More and more together: Legal family formats for same-sex and different-sex couples in European countries. Comparative analysis of data in the 
LawsAndFamiliesDatabase (Families and Societies Working Paper Series no. 75). Stockholm: Stockholm University.

Waaldijk, K. (2018). Extending rights, responsibilities and status to same-sex families: Trends across Europe. Ministry of Foreign Affairs of Denmark. Retrieved from https://rm.coe.int/extending-rights-responsibilities-and-status-to-same-sexfamilies-tran/168078f261.

Watkins, C. S. (2018). School progress among children of same-sex couples. Demography, 55(3), 799-821.

Zimmerman, L.-L., \& Nordqvist, A. (2018). Juridiskt föräldraskap. Att bli och vara förälder. RFSL. Retrieved from https://www.rfsl.se/foralder/att-bli-och-varaforalder/juridiskt-foraldraskap-efter-assisterad-befruktning/.

Open Access This chapter is licensed under the terms of the Creative Commons Attribution 4.0 International License (http://creativecommons.org/licenses/by/4.0/), which permits use, sharing, adaptation, distribution and reproduction in any medium or format, as long as you give appropriate credit to the original author(s) and the source, provide a link to the Creative Commons licence and indicate if changes were made.

The images or other third party material in this chapter are included in the chapter's Creative Commons licence, unless indicated otherwise in a credit line to the material. If material is not included in the chapter's Creative Commons licence and your intended use is not permitted by statutory regulation or exceeds the permitted use, you will need to obtain permission directly from the copyright holder. 